\title{
P L・P S 補強土の耐震性模型実験
}

\author{
東京大学大学院篠田昌弘・菊地達哉運輸省航空局 杉村佳寿 \\ 東京大学工学部 内村太郎・龍岡文夫
}

プレローディド・プレストレス補強土工法により供用時の剛性を高め、残留沈下を抑制できる。この 構造物の耐震性を検証するために、小型模型を作成し、プレロード値、プレストレス値を変化させ、 共振の影響も考慮して振動台実験を行った。また、PL/PS 補強土橋脚の固有振動数を求める式を提案 した。それらの結果、プレロードは盛土側端部の変形を弾性的にして盛土の加振時変形を減じる点で 効果があり、プレストレスは固有振動数を高め、加振時の繰返しひずみ、すなわち残留ひずみを抑制 する効果があることから、適切なプレストレス值を設定する必要性が明らかになった。本実験におい て、PL/PS 補強土構造物は共振しなければ、残留沈下は小さく、また仮に共振してもプレストレスが 抜けなければ、崩壊の危険性はないことが示された。 キーワード：プレロード、プレストレス、残留沈下,補強土構造物、耐震性、振動台実験

\section{Shaking Table Tests to investigate the seismic stability of preloaded and prestressed reinforced soil}

M.Shinoda, T.kikuchi, T.Ushimura and F.Tatsuoka ; Department of Civil Engineering, University of Tokyo H.Sugimura : Ministry of Transport

Preloaded and prestressed reinforced soil structures can have very high stiffness exhibiting very small residual settlements during service. To study the seismic stability of the structure, we performed shaking table tests with various values of preloading and prestressing. The equation to give the resonance frequency of PL/PS reinforced soil bridge pier is proposed. It is shown that preloading has effects in making the axial displacement in the side zone of backfill during cyclic loading more elastic and thereby in decreasing the residual displacement, and the prestressing has effects in increasing the resonance frequency and when the structure does not resonate, thereby in restraining the residual settlement of backfill during shaking, showing the importance of introducing sufficiently large prestress. It is shown that when the structure does not resonate, the residual settlement of PL/PS reinforced soil structure could be negligible and even when the structure resonates, PL/PS reinforced soil structures would not collapse with sufficiently high prestress being maintained.

Keywords: Preload, Prestress, Residual settlement, Reinforced soil structure, Seismic stability, Shaking table test 


\section{P L・P S 補強土の耐震性模型実験}

東京大学大学院 篠田昌弘・菊地達哉運輸省航空局 杉村佳寿

東京大学工学部 内村太郎・龍岡文夫

1.はじめに

ジオテキスタイルを用いた補強土工法は、本来弱くて柔らかい土 を利用して、強く堅い構造物を構築するのが目的である。ジオテキ スタイルは、面状の補強材であることから土との接触面積が大きく、 その結果、土をよく締め固めておけば安定した構造物になりうる。 また基礎地盤が軟弱な場合においても、多少の地盤沈下ならばそれ に伴って变形できるという柔軟性があるので、杭基礎を簡略化でき、 経济的である。さらにこの構造物は延性的であるため、大地震など でも致命的な破壊に至らず、柔軟に対応できるという利点がある。 しかし、従来の補強盛土が持つ欠点は、土がある程度変形しない と強度を発揮できないこと、(用性が比較的低いこと、令クリープ 変形が生じることなどである。これらの久点を改善し、重荘構造物 として十分な機能を持たせるために、補強盛土にあたかじめプレロ ードとプレストレスを加えるプレローディド・プレストレスト (PL/PS) 補強土工法が発案された。

この PL/PS 補強土工法では、まず張力材（タイロッド）により 盛土に鉛直方向にプレロードを加えて塑性ひずみを進行させ、供用 時の残留沈下を抑制する（図 $1 a$ 、図 $1 b$ ）。次にプレロードの一部 を除荷しプレストレス状態にすることによって盛土内の拘束圧を高 い値に維持し、供用時でのせん断抵抗力と粑性を飛躍的に増加させ

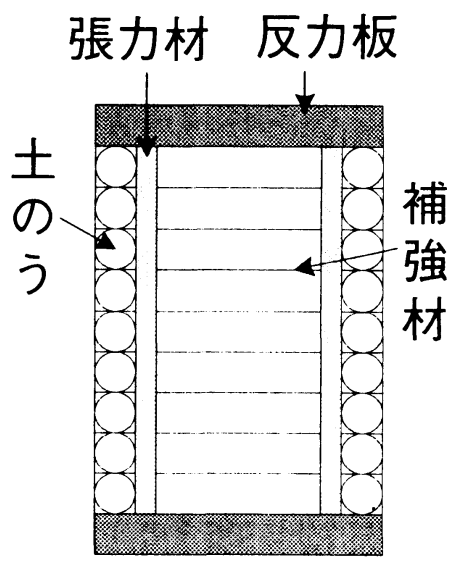

図 1 a PL/PS 補強土工法

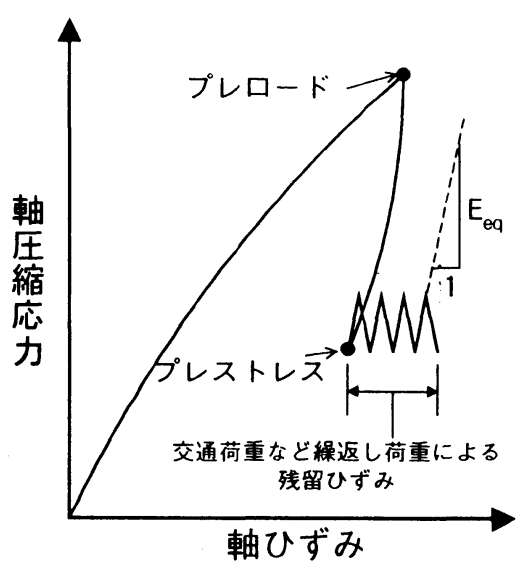

図 $1 \mathrm{~b}$ 載荷方法 ることを狙っている（文献 $2,3 ） 。$ 密な飽和砂磁は、非排水状態で等体積せん断変形すると、その高 い体積膨張特性のために有効拘束圧が大きく上昇し、排水せん断時よりもはるかに大きなせん断強度 を示すことが知られている。本研究で検討されている PL/PS 補強土工法においても、盛土がせん断 変形しょうとすると、補強材により水平方向の伸び変形とタイロッドにより鉛直方向の伸び変形が拘 束されるために等体積せん断を強制される。したがって強震時に非常に大きなせん断抵抗を示し高い 勒性を示すことが期待できる。

現在までに、PL/PS 補強土工法は実施工によりその高い剛性が実証されている（文献 4,5）。また、 室内模型実験においても交通荷重を模擬した軸方向繰返し荷重を加えた時の挙動は検討している（文 献 6)。しかし、その耐震性についてはほとんど検討されていない。また、地震時に最も危険となる 
のは、地震波の卓越振動数と構造物の固有振動数が一致して共振し、構造物の变位の振幅が非常に大 きくなるときである。共振が起こることにより、構造物は大変形を起こし、崩壊に至る可能性が非常 に大きくなる。耐震問題を扱っていく以上、共振を避けるように構造物を設計しなくてはならない。 そこで、本研究では、既往の実験（文献 6）で採用したプレロード值、プレストレス值をふまえ、高 い応力状態から低い応力状態までの様々な状態で加振し、適切なプレロードとプレストレスの関係を 考慮する。本研究の実験結果は、PL/PS 補強土工法の設計法を確立するための基礎デー夕を得るこ とを目的にしている。

\section{PL/PS 補強土模型の説明}

試験装置の概略は図 2 、写真 1 に示す。PL/PS 補強土模型は、幅 $350 \mathrm{~mm}$ 、高さ $600 \mathrm{~mm}$ であり、 補強材層の上下間隔は $50 \mathrm{~mm}$ である。補強材には幅 $3.5 \mathrm{~mm}$ 、厚さ $0.2 \mathrm{~mm}$ 長さ $350 \mathrm{~mm}$ のリン青銅 板を格子状になるように半田付けした。供試体は、多重ふるい落下装置を用いて均質な豊浦標準砂 （e=0.63、Dr=90\%）を落下させ作成した。水平方向加速度計は、供試体上部の上板に 1 個、供試体 には下から 1 層目、6 層目、11層目の土襄にそれぞれ 1 個の合計 3 個、振動台に 1 個、総計 7 個 取り付けた。加速度計は、接着剂及びガムテープを用いて、供試体にしっかりと固定した。加振中 に変位計が振動台や測定枠と一体となって動く必要があったので、鉛直变位計は、供試体中心部か

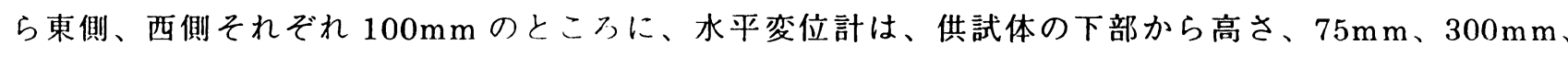
$525 \mathrm{~mm}$ ところに取り付けた。鉛直変位計には、レーザー変位計を用い、測定範囲 $\pm 2 \mathrm{~mm}$ のもを 使用した。供試体の砂部分の下に 9 湖、土辐部分の下に 6 個、合計 15 個のロードセルにより、鈶直 方向と水平方向の 2 方向の底面土压を測定した。タイロッド張力は、4 本のタイロッドの各上部に 取り付けられた張力計を用いて測定した。この張力計は供試体上部の上板と剛結されており、振動 による慣性力が実験データに入り込むのを極力省いている。PL/PS 補強土棈造物の欠点は、盛土の 圧縮沈下に伴ってタイロッドが緩みプレストレスが抜けることである。そこで、比較のためプレス トレスが抜けない様に圧力制御のエアーシリンダーを取り付け、常に一定のプレストレスが加える 実験も行った。

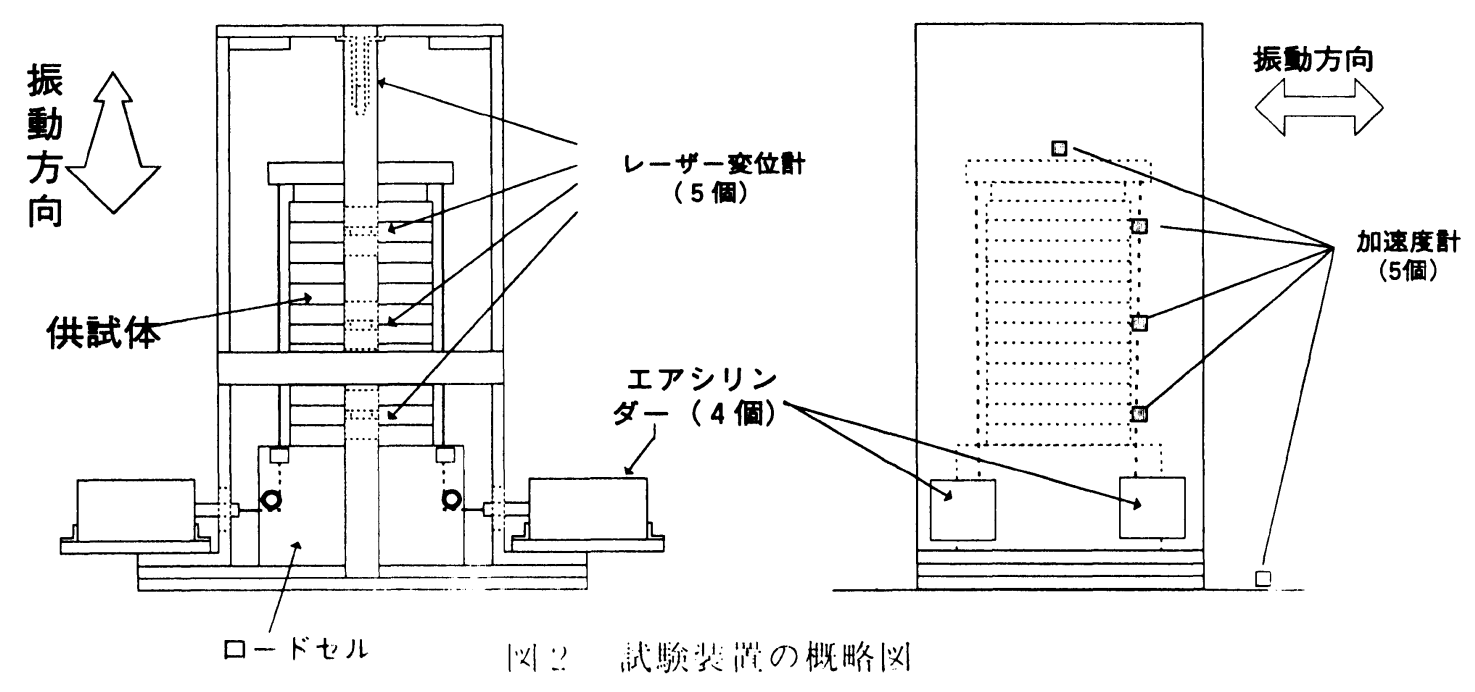




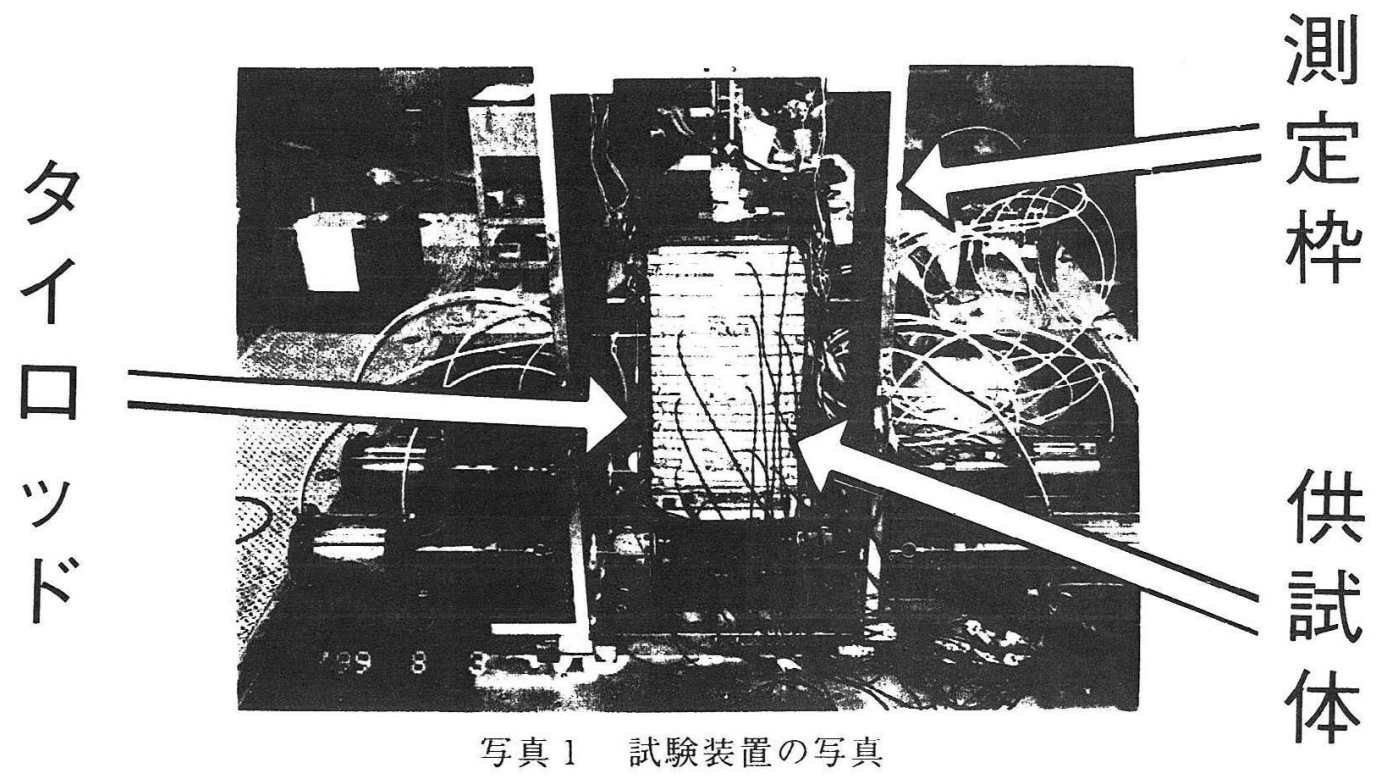

\section{3. 実験方法}

測定枠は、供試体と振動台との相対変位を測定するためのものであるので、振動台と一体となって 動く必要がある。底板及び反力板は鉄製だが、それ以外は作業性と灾全性から、比較的軽量なジェラ

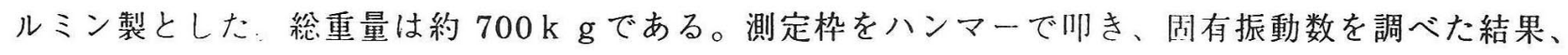
$42 \sim 43 \mathrm{H} \mathrm{z}$ であったので、 $30 \mathrm{H} \mathrm{z}$ 程度の加振までは、振動台と一体となって振動すると考えられる。

今回行った全ての実験の加振パターンは表 2 に示す通り計 17 テストである。入力加速度は $300 \mathrm{gal} 、$ $700 \mathrm{gal}$ の 2 パターンとし、入力振動数は $10 、 20 \mathrm{H} \mathrm{z}$ の 2 パターンとしたプレストレスは基本的に 100、150、200kPaの 3 パターンとした。スイイープ加振では、プレストレスを 50、100、150、200 $\mathrm{kPa}$ の 4 パターンとして、加振周波数を $0.2 \mathrm{~Hz} / \mathrm{sec} て ゙$ 増加させることで固有振動数を調べた。

表 2 加振パターン

\begin{tabular}{|c|c|c|c|c|}
\hline $\begin{array}{c}\text { 入力加速度 } \\
(\mathrm{gal})\end{array}$ & $\begin{array}{c}\text { 入力波振動数 } \\
(\mathrm{Hz})\end{array}$ & $\begin{array}{c}\text { プレロード } \\
(\mathrm{kPa})\end{array}$ & $\begin{array}{c}\text { プレストレス } \\
(\mathrm{kPa})\end{array}$ & エアーシリンダー \\
\hline 300 & 10 & 100 & 100 & $\times$ \\
\hline 300 & 10 & 200 & 100 & $\times$ \\
\hline 300 & 10 & 200 & 150 & $\times$ \\
\hline 300 & 10 & 200 & 200 & $\times$ \\
\hline 700 & 10 & 200 & 100 & $\times$ \\
\hline 700 & 20 & 200 & 100 & 0 \\
\hline 700 & 20 & 200 & 100 & $\times$ \\
\hline 100 & Sweep & 50 & 50 & $\times$ \\
\hline 100 & Sweep & 100 & 100 & $\times$ \\
\hline 100 & Sweep & 150 & 150 & \\
\hline 100 & Sweep & 200 & 200 & $\times$ \\
\hline
\end{tabular}




\section{4. 実験結果}

\section{4 . 1 ブレロードの効果}

まず地震荷重が作用した場合のプレロードの効果を確認するために、入力加速度 $300 \mathrm{gal}$ 、振 動数 $10 \mathrm{~Hz}$ でプレストレスとプレロードが共に $100 \mathrm{kPa}$ の場合（PL100PS100）とプレストレス がプレロードの半分の場合（PL200PS100）の加振実験を行った。プレストレスが $100 \mathrm{kPa}$ のと き、固有振動数は $20 \mathrm{~Hz}$ であることがわかっており（文献 7)、今回の $10 \mathrm{~Hz}$ での加振では共振 の影響を考える必要はない。沈下量の時系列で比較してみると、プレストレスがプレロードの半 分の場合（PL200PS100）、曲げ 変形による側端部での軸ひずみを より抑えることができ、沈下量は 相対的に小さい（図 3)。しかし、 プレロードとプレストレスが等し い場合（PL100PS100）、プレロ ードによる事前の目: 縮が不十分で あるために土の塑性:変形が起こり、 供試体側端部での繰返し軸圧縮作 用により残留ひずみが進行するた めと思われる。よってプレロード は PL/PS 補強盛士:の耐震性を向

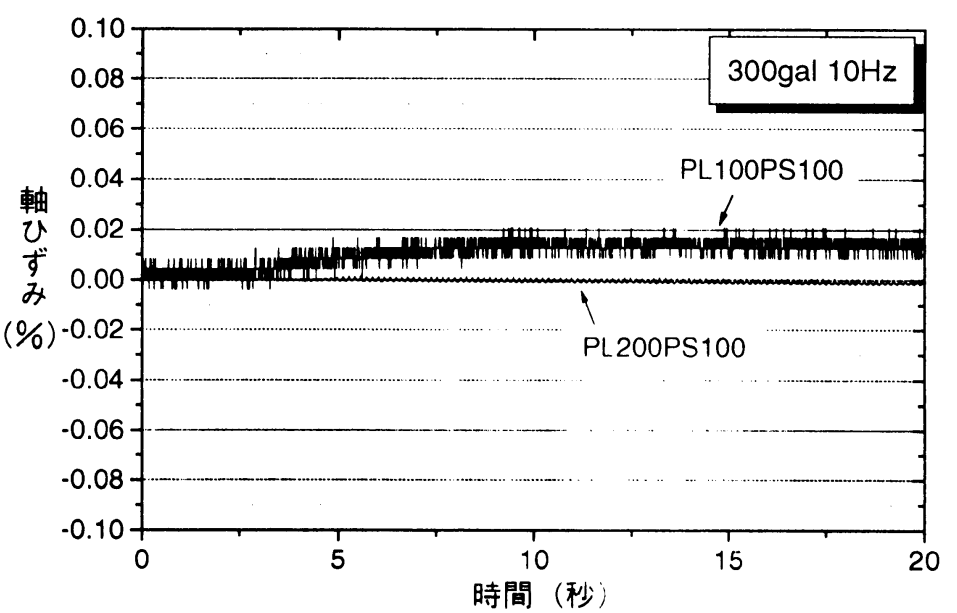

図 3 プレロードの効果 上させる効果がある。

\section{2 プレストレスの効果}

プレストレスと固有振動数の関 係を明確にするために、プレロー ドとプレストレスが等しい状態で 入力加速度 $300 \mathrm{gal}$ 、入力振動数 $2 \mathrm{~Hz} \sim 30 \mathrm{~Hz}$ まで $0.2 \mathrm{~Hz} / \mathrm{sec}$ の割 合で增加させながらスイープ加振 を行った。供試体は、PL50PS50、 PL100PS100、PL150PS150、 PL200PS200の計 4 つで比較し た。その結果、図 4 に示す結果が 得られた。ここでのプレストレス

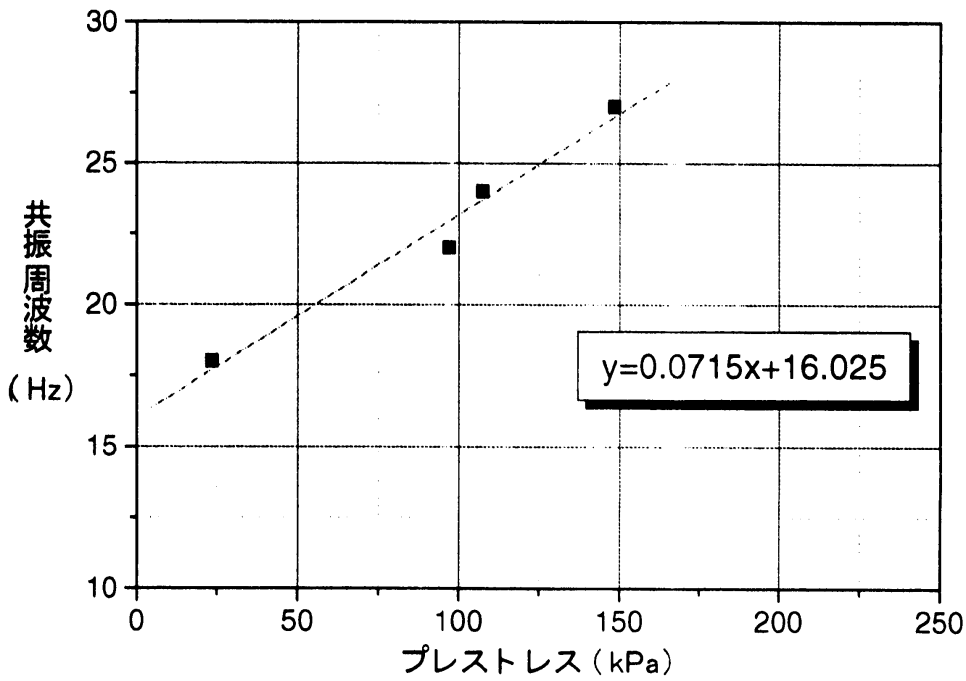

図 4 プレストレスの效果 
は加振によるプレストレスの抜けも考慮し、共振時でのプレストレス值とした。構造物の固有振 動数は主に形状と剛性に大きく依存する。この 4 つの供試体は同一であるとみなせるので、この 固有振動数に大きく関わっているのは補強盛土の剛性であると考えられる。既往の研究によれば、 繰返し載荷時の鉛直方向のヤンク率 $E_{e q}$ 、 せん断剛性率 $G_{e q}$ と有効鉛直応力 $\sigma_{\mathrm{v}}$ 、水平応力 $\sigma_{\mathrm{h}}$ の 間には、次式が成立することがわかっている。

$$
E_{e q}=E_{0} \cdot\left(\frac{\sigma_{v}}{\sigma_{0}}\right)^{m}, \quad G_{e q}=G_{0}\left(\frac{\sigma_{v}+\sigma_{h}}{2 \sigma_{0}}\right)^{m}
$$

ここで、 $E_{0} 、 G_{0}$ は、 $\sigma_{v}=\sigma_{0}$ のときの $E_{e q} 、 G_{e q}$ である。上式に示すように、軸圧縮応力が高い ほど、土の剛性が大きくなる。この関係を PL/PS 補強盛土に適用すると、圧縮応力を担ってい るのはプレストレスであり、プレストレスの值に応じてヤング率とせん断剛性率が変化するとい うことになる。以上のことにより、補強盛土の固有振動数に大きく関わっているのは、プレスト レスの值であると考えられる。

PL/PS 軸方向繰返し室内模型実験な どの既往の研究(文献 6)により鉛直鉛直 荷重が加わった時、プレストレスが高す ぎると、破壊応力状態に接近するため残 留ひずみが大きくなり、プレストレスが 小さすぎると、剛性の低下により残留ひ ずみが大きくなるので、適切なプレスト レス載荷が必要になることがわかってい る。図 5 は一定のプレロード荷重 $(200 \mathrm{kPa})$ でプレストレスを 3 パター ン変化させた振動台実験（入力：300gal、

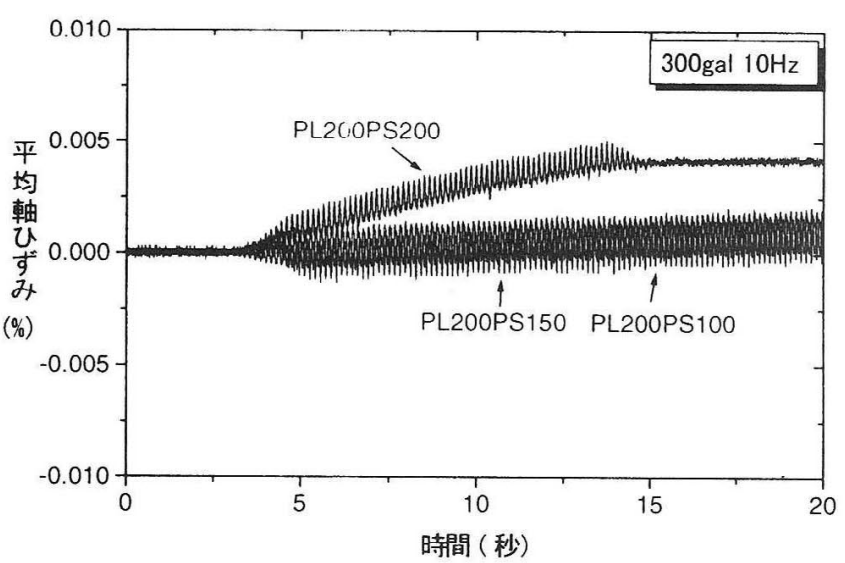

図 5 プレストレスの効果

$10 \mathrm{~Hz}$ ）による平均軸ひずみの時系列である。実験結果から、プレストレス荷重が高いと残留沈 下が増加してしまうことがわかる。よって、構造物の耐震性を向上させるためには、高いプレス レス荷重に設定し共振周波数を高めればよいが、プレストレス荷重を高くしすぎると、残留沈下 が增加してしまうので、高すぎず、低すぎない適切なプレストレス荷重に設定したほうがよい。

\section{3 エアーシリンダーを使用したブレストレスの抜け防止対策の効果}

PL/PS 補強土構造物の耐震性を向上させるためには、振動中でもプレストレスの値が維持で きるような工夫、できれば盛土の高さが増加しない工夫が必要である。そこで、振動中でもエア ーシリンダーをタイロッドに取り付けて加振した。加振中はエアーシリンダーからの空気の出入 りがないようにしているので、加振中はダンパーつきのバネとなっており、盛土の高さの増加を 抑える機能があり、長期的にはダンパーのないバネとして機能する。ここではプレストレス荷重 
をプレロード荷重の半分に設定し、プレ ロード $200 \mathrm{kPa}$ 、プレストレス $100 \mathrm{kPa}$ とした。入力加速度はレベル II 地震に相 当する $700 \mathrm{gal}$ で、共振振動数からはず れた $10 \mathrm{~Hz}$ と共振振動数である $20 \mathrm{~Hz}$ で 加振した。各試験ごとの供試体上板にお ける応答加速度を図 6 に示す。入力振動 数が $10 \mathrm{~Hz}$ の場合、応答倍率がほほ 1 で、 一体となって振動している。しかし共振 振動数付近 $(20 \mathrm{~Hz})$ では、非常に大き な応答をしている。エアーシリンダーを 設置してない場合、共振すると沈下量の
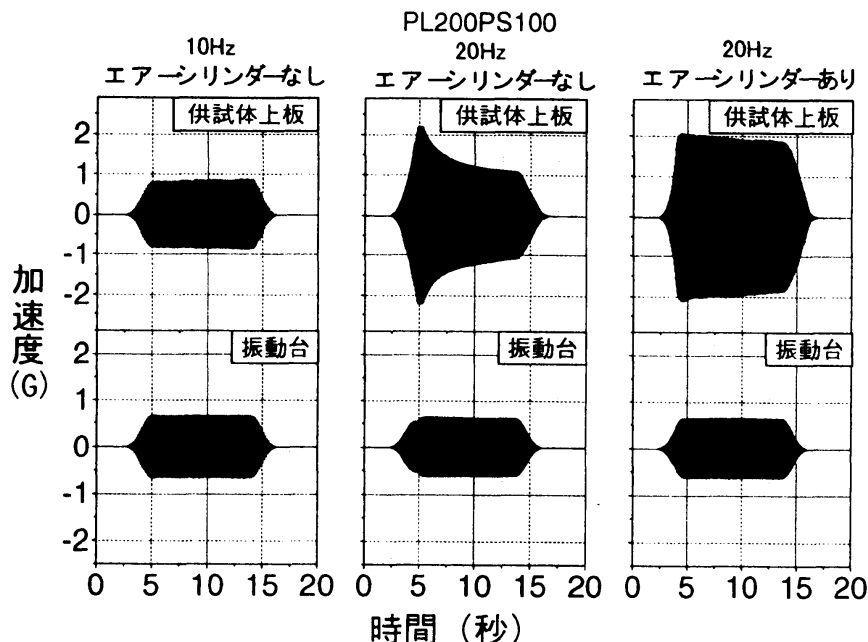

図 6 エアーシリンダー設置の効果

增加に伴ってプレストレスが隇少し固有振動数が低下し共振状態からはずれるので、5 秒後のピ 一ク以降は応答が小さくなる。しかしエアーシリンダーを設置し、プレストレスを加振中ほほー 定にすると供試体の固有振動数は変化せず、共振し続けることになる。共振が続くことにより沈 下量は大きくなる（図 7 ）。しかし、実際の地震波はランダム波であり、様々な振動成分を含ん でいるから、実際にはこのことによって耐震性が下がることにはならない。むしろ、プレストレ スが抜けると、供試体の剛性が低下し、共振振動数が変化することで何度も共振現象が生じる可 能性があるので、本実験のようにプレストレスを一定に保た、共振時間を非常に短くするほうが よい。実施工においても、プレストレスの值を維持できる機能を持たせることができれば、高い 耐震性を有する構造物になりうる。

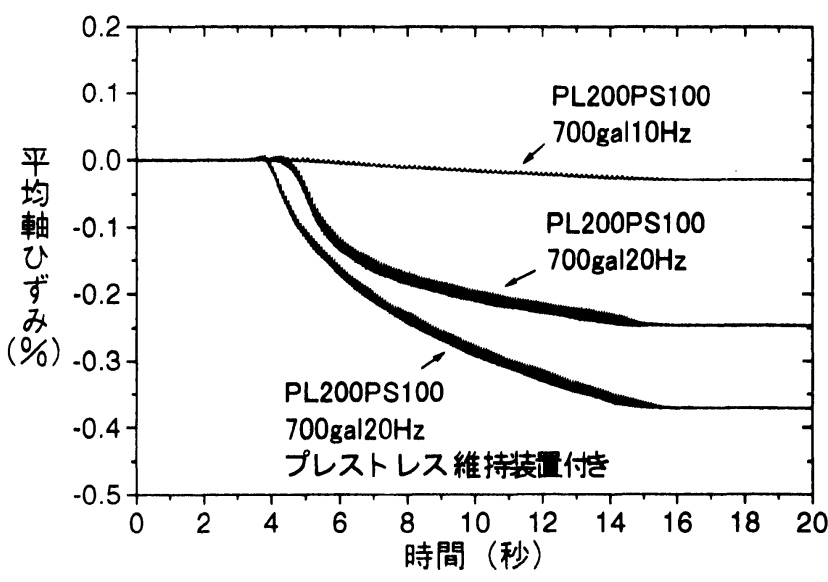

図 7 エアーシリンダー設置の効果

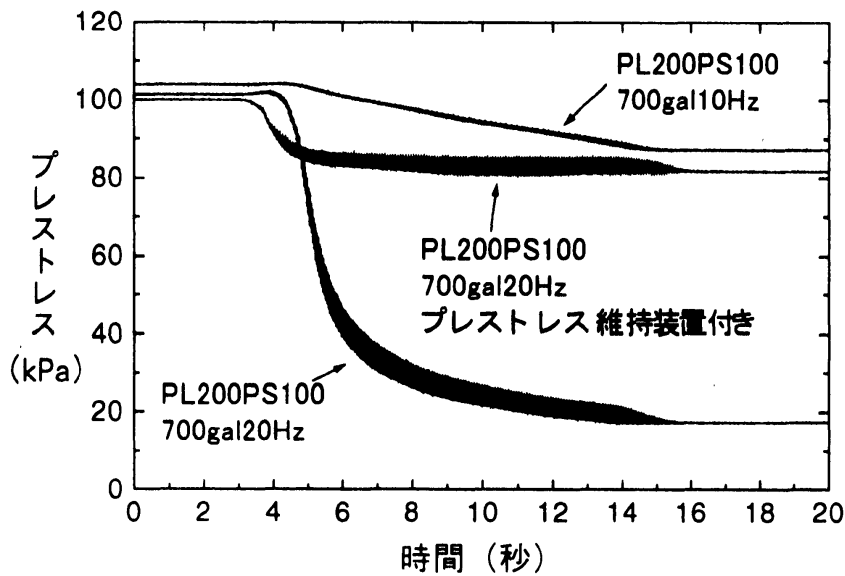

図 8 エアーシリンダー設置の効果

\section{PL/PS 構造の振動のモデ化}

PL/PS 補強土構造物の耐震性を考える上で最も重要なことは、共振させないということである。 ここでは PL/PS 補㢱土構造物の固有振動数を計算で求めるため連続体とみなしてモデル化を行う。 
具体的には質量 $\mathrm{m}$ の上載物を持つ質量 $\mathrm{M}$ の橋脚として梁の曲げ問題と考えて固有振動数を算出する

（図 9）。曲げ剛性 $\mathrm{EI}$ 、高さ $\mathrm{H}$ の梁に荷重 $\mathrm{P}$ が水平方向に加わったときのたわみ曲線 $v(x)$ は、

$$
v(x)=\frac{P}{6 E I} x^{3}-\frac{P H^{2}}{2 E I} x+\frac{P H^{3}}{3 E I}=\frac{P H^{3}}{3 E I}\left(\frac{x^{3}}{2 H^{3}}-\frac{3 x}{2 H}+1\right) \ldots
$$

また、たわみ角と曲げモーメントは、以下のようになる。

$$
\begin{aligned}
& \theta(x)=\frac{d v(x)}{d x}=\frac{P H^{2}}{2 E I}\left(\frac{x^{2}}{H^{2}}-1\right) \cdots \\
& M(x)=-E I \frac{d^{2} v(x)}{d x^{2}}=-P x \cdots \quad(3)
\end{aligned}
$$

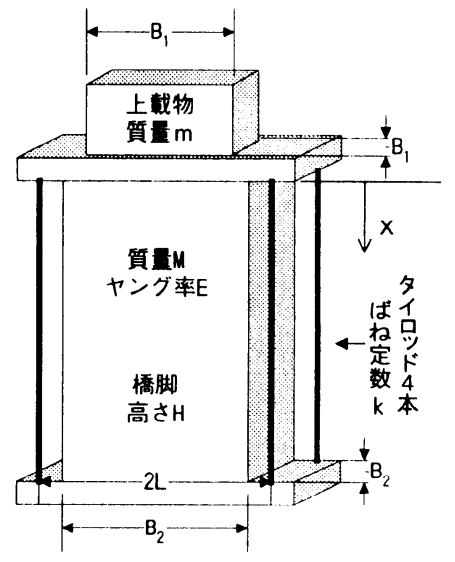

図 9 モデル化

$$
\begin{aligned}
& u_{\max }=\frac{P H^{3}}{3 E I} \cdots \\
& \theta_{\max }=\frac{P H^{2}}{2 E I} \cdots
\end{aligned}
$$

であるので、共振時の上載物の水平変位と回転角を $u_{1}(t) 、 \theta_{1}(t)$ とすると

$$
\begin{aligned}
& u_{1}(t)=u_{\max } \cos (\omega t-\varphi)=\frac{P H^{3}}{3 E I} \cos (\omega t-\varphi) \cdots \\
& \theta_{1}(t)=\theta_{\max } \cos (\omega t-\varphi)=\frac{P H^{2}}{2 E I} \cos (\omega t-\varphi) \cdots
\end{aligned}
$$

とおくことにする。このとき、橋脚の水平変位及び回転角を $u_{2}(x, t) 、 \theta_{2}(x, t)$ とすると

$$
\begin{aligned}
& u_{2}(x, t)=u_{1}(t)\left(\frac{x^{3}}{2 H^{3}}-\frac{3 x}{2 H}+1\right)=\frac{P H^{3}}{3 E I} \cos (\omega t-\varphi)\left(\frac{x^{3}}{2 H^{3}}-\frac{3 x}{2 H}+1\right) \cdots \\
& \theta_{2}(x, t)=\frac{P H^{2}}{2 E I}\left(\frac{x^{2}}{H^{2}}-1\right) \cos (\omega t-\varphi) \cdots(9)
\end{aligned}
$$

として表される。

ここで、系全体の運動エネルギーを $K(t)$ と置くと

$$
K(t)=\frac{1}{2} \cdot m \cdot \dot{u}_{1}^{2}+\int_{0}^{H} \frac{1}{2} \cdot M_{\rho} \cdot \dot{u}_{2}^{2} d x+\frac{1}{2} \cdot I_{1} \cdot \dot{\theta}_{1}^{2}+\frac{1}{2} \cdot I_{2} \cdot \dot{\theta}_{2} d x \cdots
$$

となる。ここでは滅衰によって失われるエネルギーは無梘している。ただし、

$m:$ 上載物の質量 $(\mathrm{kg})$

$M_{\rho}$ : 単位長さ当たりの質量 $(\mathrm{kg} / \mathrm{cm})$ 
$I_{1}$ : 上載物の慣性モーメント

$I_{2}:$ 橋脚の慣性モーメント

$B_{1}$ : 上載物の幅、奥行き $(\mathrm{cm})$

$B_{2}:$ 橋脚の幅、奥行き $(\mathrm{cm})$

である。また、単位長さ当たりの質量 $M_{\rho}$ は、以下の式で求められる。

$$
M=M_{\rho} H \cdots\left(\begin{array}{ll}
1 & 1
\end{array}\right)
$$

上載物と橋脚の慣性モーメントは、それぞれ

$$
\begin{aligned}
& I_{1}=\frac{m B_{1}{ }^{2}}{12}+m H^{2} \\
& I_{2}=\frac{M}{12}\left(B_{1}{ }^{2}+H^{2}\right)+\frac{M H^{2}}{4}=\frac{M}{12}\left(4 H^{2}+B_{1}{ }^{2}\right)
\end{aligned}
$$

となる。式（１００）を整理すると、

$$
K(t)=\frac{\omega^{2} P^{2} H^{6}}{E^{2} I^{2}}\left\{\frac{m}{18}+\frac{11 M}{840}+\frac{m}{8}\left(\frac{B_{1}{ }^{2}}{12 H^{2}}+1\right)+\frac{M}{180}\left(\frac{B_{2}{ }^{2}}{H^{2}}+4\right)\right\} \sin ^{2}(\omega t-\varphi)
$$

ここで、運動エネルギーKの最大值を $K_{\max }$ とすると

$$
K_{\max }=\frac{72 \omega^{2} P^{2} H^{6}}{E^{2} B_{2}{ }^{8}}\left\{\frac{m}{9}+\frac{11 M}{420}+\frac{m}{4}\left(\frac{B_{1}{ }^{2}}{12 H^{2}}+1\right)+\frac{M}{90}\left(\frac{B_{2}{ }^{2}}{H^{2}}+4\right)\right\} \cdots
$$

となり、断面二次モーメントは以下の式で求められる。

$$
I=\frac{B_{2}^{4}}{12}
$$

となる。

一方、橋脚のひずみエネルギーV $(t)$ は

$$
\begin{aligned}
& V(t)=\frac{1}{2} \int_{0}^{H} E I\left(\frac{d^{2} u_{2}}{d x^{2}}\right)^{2} d x=\int_{0}^{H} \frac{(-P x \cos (\omega t-\varphi))^{2}}{2 E I} d x=\frac{P^{2} H^{3}}{6 E I} \cos ^{2}(\omega t-\varphi) \\
& =\frac{2 P^{2} H^{3}}{E B_{2}{ }^{4}} \cos ^{2}(\omega t-\varphi)
\end{aligned}
$$

となり、ここでのひずみエネルギーは、せん断力の影響を無視していることに注意すべきである。ま た、4本のタイロッドに蓄えられるエネルギー $T(t)$ は、

$$
T(t)=4 \cdot \frac{1}{2} k\{\delta H(t)\}^{2} \cdots\left(\begin{array}{ll}
1 & 5
\end{array}\right)
$$


である。 $\delta H(t)$ は、タイロッドの長さの変化量であり、以下の式で求められる。

$$
\delta H(t)=L \theta_{1}(t)=\frac{P H^{2} L}{2 E I} \cos (\omega t-\varphi) \cdots
$$

よって、タイロッドに蓄えられるエネルギー $T(t)$ は、

$$
T(t)=4 \cdot \frac{1}{2} k\left\{\frac{P H^{2} L}{2 E I} \cos (\omega t-\varphi) \cdot\right\}^{2}=\frac{72 k P^{2} H^{4} L^{2}}{E^{2} B_{2}^{8}} \cos ^{2}(\omega t-\varphi) \cdots \quad\left(\begin{array}{ll}
1 & 7
\end{array}\right)
$$

となる。ここで系全体のひずみエネルギーを $U(t)$ とおくと、

$$
\begin{aligned}
& U(t)=V(t)+T(t) \\
& \left.=\left(\frac{2 P^{2} H^{3}}{E B_{2}{ }^{4}}+\frac{72 k P^{2} H^{4} L^{2}}{E^{2} B_{2}{ }^{2}}\right) \cos ^{2}(\omega t-\varphi)^{\cdots(18}\right)
\end{aligned}
$$

として、 $U(t)$ の最大値を $U_{\max }$ とすると

$$
U_{\operatorname{nax}}=\frac{2 P^{2} H^{3}}{E B_{2}{ }^{4}}+\frac{72 k P^{2} H^{4} L^{2}}{E^{2} B_{2}{ }^{8}} \cdots\left(\begin{array}{ll}
1 & 9
\end{array}\right)
$$

となるので、 $K_{\max }=U_{\max }$ より

$$
\begin{aligned}
& \left.\frac{72 \omega^{2} P^{2} H^{6}}{E^{2} B_{2}^{8}}\left\{\frac{m}{9}+\frac{11 M}{420}+\frac{m}{4}\left(\frac{B_{1}{ }^{2}}{12 H^{2}}+1\right)+\frac{M}{90}\left(\frac{B_{2}{ }^{2}}{H^{2}}+4\right)\right\}_{\ldots(20}\right) \\
& =\frac{2 P^{2} H^{3}}{E B_{2}{ }^{3}}+\frac{72 k P^{2} H^{4} L^{2}}{E^{2} B_{2}^{8}}
\end{aligned}
$$

$\omega$ を求め、固有振動数を求めると、

$$
f_{n}=\frac{\omega}{2 \pi}=\frac{1}{2 \pi} \sqrt{\frac{2 E B_{2}{ }^{4}+72 k H L^{2}}{2 H\left\{m\left(\frac{3 B_{1}{ }^{2}+52 H^{2}}{4}\right)+M\left(\frac{14 B_{2}{ }^{2}+89 H^{2}}{35}\right)\right\}}} \cdots
$$

となる。PL/PS 補強土模型の室内繰返し載荷実験 結果から求められたヤング率とプレストレスの関係 は、

$$
E=26835\left(\sigma_{0}\right)^{0.35}(k P a)
$$

である。今回の実験結果をあてはめると、図10の ようになり、計算結果は実験結果をほほ正確に表現

していると思われる。

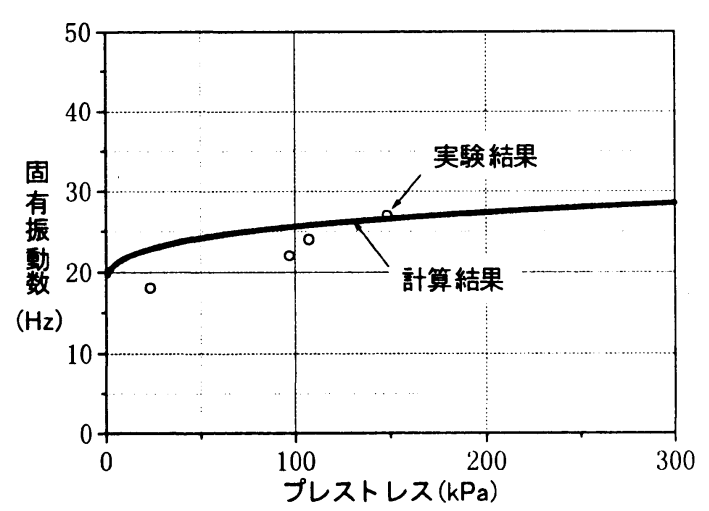

図10 計算結果 
6.まとめ

PL/PS 補強土工法による橋脚模型の振動台実験を行った。その結果、プレストレス荷重により固 有振動数が大きく变化し、プレストレス荷重が高いほど固有振動数が高くなることがわかった。今 回行った比較的高い応力状態では、共振しなければ曲げ変形が小さいため、側端部が繰返し軸圧縮 状態となっても応力・ひずみ関係は弾性的であり、残留沈下は進まず、したがってプレストレスの 抜けはほとんどない。逆に、共振すれば激しい曲げ変形が生じ、側端部の繰返し軸圧縮応力の振幅 が大きくなり、盛土の応力・ひずみ状態が弾性域を越えるため、残留沈下が進み、プレストレスが 抜ける。さらに、プレロード荷重からある程度除荷して、プレストレス状態にすれば、繰返し軸圧 縮載荷が弾性域で行われるため、残留沈下を抑えるのに有効である。

以上のことより、PL/PS 補強土構造物の施工では以下のことに注意する必要がある。

1. 施工時に十分な締固めにより密度を高める。

2.プレロ゙ード時に十分な初期沈下を生じさせておく。

3 . 固有振動数を高め共振しないように適切なプレストレスを設定する。

4.プレロードの半分の值まで除荷し、それをプレストレス荷重とする。

5.共振してもプレストレスが报けない構造にする。

\section{参考文献：}

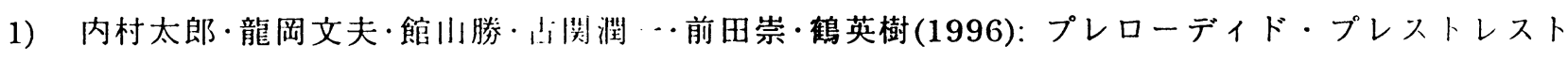
補強盛土のメカニズム・原理実験・実大模型実験・実施工,第 11 回ジオセンセティックスシン ポジウム発表論文集,国際ジオセンセティックス学会日本支部,72-81 頁

2) Tatsuoka, F., Uchimura, T. and Tateyama, M.(1996a) "Preloaded and prestressed reinforced soil", Soils and Foundations, JGS, Vol.37, No.3, pp.79-94

3) Tatsuoka, F., Tateyama, M, Uchimura, T. and Koseki, J.(1996b) "Geosynthetic-Reinforced Soil Retaining Walls as Important Permanent Structures, The 1996-1997 Mercer Lecture", Geosynthetic International, IGS, Vol.4, No. 2, pp.81-136

4) 内村太郎·中村宏之·丸山大介·舘山勝·古賀徹志(1997): プレロディド・プレストレスト補強 土橋脚の実施工,第 32 回地盤工学研究発表会発表講演集,pp2477-2478

5) 内村太郎・龍岡文夫·古関潤一・舘山勝・古賀徹志(1998): プレローディド・プレストレスト補 強土の現場計測結果と設計法・施工法の提案,ジオシンセティック論文集,pp75-84

6) M.Shinoda, T.Uchimura, N.Maruyama, F.Tatsuoka(1999) "Effects of preloading and prestressing on the vertical stiffness of GRS", Proceedings of the 11th ARC on Soil Mechanics and Geothecnical Engineering, Vol.1, pp.419-422

7）杉村佳寿・篠田昌弘・菊地達哉・龍岡文夫・内村太郎 (1998)：プレローディド・プレストレス 卜（PL・PS）補強盛土の水平方向変形特性に関する研究, 第 13 回ジオセンセティックスシ ンポジウム発表論文集,国際ジオセンセティックス学会日本支部,pp270-277 